This is a pre-copyedited, author-produced version of an article by Malcolm M. Combe accepted for publication by Oxford University Press following peer review in Legal Strategies for the Development and Protection of Communal Property edited by Ting Xu and Alison Clarke (Proceedings of the British Academy, 216, 79-101; (C) The British Academy 2018).

\title{
Community rights in Scots property law
}

Since the establishment of the Scottish Parliament at Holyrood by the Scotland Act 1998, the Scottish Parliament has embarked on a programme of community-oriented land reform to allow for redistribution of land to Scottish communities. Eligible community bodies have rights of varying strengths under the Land Reform (Scotland) Act 2003, and will soon benefit from a suite of rights Community Empowerment (Scotland) Act 2015 and the Land Reform (Scotland) Act 2016. The model that has been introduced to Scots law, and Scots land law in particular, makes for an interesting comparator for other jurisdictions. This paper explains the background to, the operation of and the future scope of those rights.

\section{Introduction}

On 16 March 2016, the Scottish Parliament at Holyrood voted through what is now the Land Reform (Scotland) Act 2016 (asp 18) ('the 2016 Act') by 108 votes to 14. This was the second statute branded as land reform passed at Holyrood since the millennium, with the Land Reform (Scotland) Act 2003 (asp 2) ('the 2003 Act') preceding it (by a slightly less comprehensive 101 votes for and 19 against).

The short titles of those two statutes, not to mention the generally cross-political party support for the contents of them, ably demonstrate that land reform is in the air in Scotland. Both statutes contain provisions that aim to facilitate or, in some cases, compel transfer of land from an existing landowner to a community body. The 2016 Act also contains provisions about engaging communities in decisions relating to land that may affect them. Away from the land reform brand, the Community Empowerment (Scotland) Act 2015 (asp 6) ('the 2015 Act') also introduced new rights of community acquisition that can be deployed against private landowners, together with a scheme that allow communities to take on assets from the public sector. That there has been so much recent legislation makes Scotland a prime candidate for examining legal strategies for the development and regulation of communal property.

These measures are ripe for analysis, but such analysis should not exclude the distinctive features of the well-developed system of property law that existed in Scotland before the recent legislation was passed. Scots law is generally described as being a 'mixed' legal system, formed of a civilian (Roman) foundation that has been overlaid by common law (English) influence. It would be fair to say that the mixture of Scots property law has more of a civilian flavour to it. Within that, a strong right of ownership gives much autonomy to the owner of a thing, but there are aspects of Scots law that can also give communities certain rights in relation to property. This chapter will set out some key points of Scots property law and where concepts of community feature within it, before explaining why new community 
rights were introduced, where the new rights slot into the Scottish system, and offering some observations about what the rights mean for Scottish communities.

\section{Scots property law and community generally}

In common with most civilian traditions, ${ }^{1}$ Scots property law is unititular. ${ }^{2}$ That is to say, there is only one title of ownership in any thing at any one time. With the exception of indivisible common or joint ownership by more than one individual (discussed below), the Scottish concept of ownership 'necessarily excludes every other person but the proprietor' ${ }^{3}$

This has not been changed by any of the recent reforms brought in by the Scottish Parliament. As we shall see, the land reform measures that communities can benefit from operate within a single title per asset system, ${ }^{4}$ allowing community members to associate together into a suitable body and then in turn allowing that body to acquire sole title to local assets.

To set the scene, it might be helpful to clarify a number of aspects of Scots law that are of at least tangential relevance to conceptions of property and community. These clarifications relate to: the recent abolition of feudal tenure and title conditions; regulation of coownership; and the idiosyncratic systems of commonty, common grazings and common good property.

\section{Feudalism and title conditions}

Not much needs to be said about the system of feudal tenure that used to prevail in most of Scotland, save to note that it was swept away by the Abolition of Feudal Tenure etc. (Scotland) Act 2000 (asp 5). ${ }^{5}$ It merits a brief mention here because there used to be different levels of land tenure, with a vassal holding from a feudal superior who ultimately held from the Crown. ${ }^{6}$ This created something of a hierarchical community, in which those towards the bottom of the feudal chain could be held to account for their actions by those above them. On 28 November 2004 all vassals who held the dominium utile - i.e. the substantial right in land

\footnotetext{
${ }^{1}$ Consider R. Zimmermann, K. Reid and D. Visser, Mixed Legal Systems in Comparative Perspective: Property and Obligations in Scotland (Oxford, Oxford University Press, 2005).

${ }^{2}$ On Scots property law generally, see K. G. C. Reid, The Law of Property in Scotland (Edinburgh, LexisNexis Butterworths, 1996) and G. L. Gretton and A. J. M. Steven, Property, Trusts and Succession, 2nd edn (Haywards Heath, Bloomsbury, 2013).

${ }^{3}$ J. Erskine An Institute of the Law of Scotland, first edition (Edinburgh, 1773; reprinted as Old Studies in Scots Law, vol. 5, Edinburgh, Edinburgh Legal Education Trust, 2014) II, 1, 1. This was confirmed in Burnett's Tr v. Grainger, 2004 SLT 513.

${ }^{4}$ Or, as noted in an earlier article, 'Scottish land reform is taking place within a decidedly unititular regime.' $M$. M. Combe, 'Parts 2 and 3 of the Land Reform (Scotland) Act 2003: A Definitive Answer to the Scottish Land Question?’, Juridical Review, 2006, 195-227, 225.

${ }^{5}$ K. G. C. Reid, The Abolition of Feudal Tenure in Scotland (Edinburgh, LexisNexis Butterworths, 2003). Incidentally, the Norse influenced Northern Isles, Orkney and Shetland, did not receive feudalism to the same extent as the rest of Scotland.

${ }^{6}$ Gretton and Steven, Property, Trusts and Succession, Appendix.
} 
enjoyed by the vassal, roughly equivalent to the Anglo-American fee simple ${ }^{7}$ - of the land were converted into outright owners, so this is now largely of historical interest.

One reason that feudalism lingered for so long in Scotland was because of its important role in the regulation of land use. This allowed real burdens to be imposed on areas of land for the benefit of a feudal superior (or, in some circumstances, another area of land). Where a large area of land was subject to the same or similar burdens, there was something of a community in existence, with shared obligations and rights relating to other members of that community.

Real burdens - which might alternatively be referred to as real conditions or (in English terminology) restrictive and positive covenants - attach to immoveable property, binding the current owner and any successors in title to do, or not to do, certain acts in situations defined in their title deeds. These might operate to oblige the landowner to (for example) build using granite, but not above a certain height. These devices were important to the modern development of Scotland's cities, most notably Edinburgh's New Town. ${ }^{8}$ Traditionally these obligations would have been enforced by a feudal superior, serving as a pseudo-planning regime in the absence of a modern system of public control, ${ }^{9}$ but following the decline and now abolition of feudalism in Scotland real burdens tend to be enforced by neighbouring proprietors. One term used in the Title Conditions (Scotland) Act 2003 (asp 9), the framework act that regulates real burdens and contains important provisions for the law relating to servitudes (easements), is 'community burden'. ${ }^{10}$ What might make this relevant to those interested in community management of assets is that this statute was enacted following a major study into the utility of real obligations, and it was recognised that these obligations could have a positive role to play in a modern system of property law. ${ }^{11}$ Members of (ownership) communities can have a role within that.

\section{Co-ownership - Common and Joint Property}

As noted already, Scots law is unititular. That does not prevent shared ownership of an asset. This is often encountered with spouses, civil partners or cohabitants co-owning a family

\footnotetext{
${ }^{7}$ An example of this equivalence was provided by UK tax legislation. Before its amendment to reflect the abolition of the feudal system in Scotland, section 96(1) of the Value Added Tax Act 1994 provided " "fee simple” ... in relation to Scotland, means the estate or interest of the proprietor of the dominium utile ... '. ${ }^{8}$ See Reid, The Law of Property in Scotland, paragraphs 376-385. As Reid notes (paragraph 376), their importance was not restricted to Edinburgh, with a key early case relating to Bon Accord Square in Aberdeen: Tailors of Aberdeen $v$ Coutts, (1840) 1 Rob 296, HL.

${ }^{9}$ See K. G. C. Reid, 'Real Rights and Real Obligations' in S. Bartels and M. Milo (eds), Contents of Real Rights (Nijmegen, Wolf Legal Publishers, 2004), 25-45, pp. 35-37. On the transition away from feudalism, see Reid, The Abolition of Feudal Tenure in Scotland. As for the current non-pseudo-planning regime in Scotland, the primary statute is the Town and Country Planning (Scotland) Act 1997. That regime, to a certain extent, allows communities to be involved in the planning process, but that is beyond the scope of this chapter.

${ }^{10}$ Section 25.

${ }^{11}$ See, for example, the observations of the Government formed Land Reform and Policy Group in their papers Identifying the Solutions (September 1998) at paragraph 5.1 and Recommendations for action (January 1999) at paragraph 2.4. The Scottish Law Commission Report on Real Burdens (Scot Law Com No.181, 2000) considered the arguments in favour of abolishing real burdens entirely, but rejected them: at paragraphs 1.141.21. See also Scottish Law Commission Discussion Paper on Real Burdens (Scot Law Com D.P. No.106, 1998). Both papers are available at www.scotlawcom.gov.uk.
} 
home. Another example of people associating together to manage property would be where such property is within the patrimony of a trust and those people administer it as trustees. ${ }^{12}$

Different regimes prevail to regulate those exemplar situations in Scots property law. Since the important case of Magistrates of Banff $v$ Ruthin Castle $L t d,{ }^{13}$ it is generally accepted that there is a binary structure of co-ownership in Scots Property law. The first exemplar would see people co-owning on the basis of 'common property', the latter being 'joint property'. The terminology is suboptimal, although fittingly common property is the more common situation. " "Joint ownership” is the special case, the main example being in the law of trusts.' 14

Comparison with another legal system is instructive: in South Africa the equivalent to common property is referred to as 'free co-ownership', while joint property can be juxtaposed with 'bound co-ownership'. ${ }^{15}$ This highlights the key distinction between the two Scots systems of co-ownership: in a situation of common property an owner has a right to sell her share and indeed insist on a court action to divide the asset or sell the asset and divide the proceeds, ${ }^{16}$ but such a route is not ordinarily available for a trustee in a trust. ${ }^{17}$

The relevance of this for the present discussion is that a loose community of interest (that is to say, individuals with a common purpose) of potentially any number of people ${ }^{18}$ could come together to buy an asset on a shared basis, and if they did so via the simple expedient of sharing a title they would default into a situation of common property. In that circumstance, use (and overuse) of the asset and exit routes from ownership of it would be regulated by the rules applicable to that regime. ${ }^{19}$ However, the susceptibility of the relationship to being ended by a disgruntled co-owner at any time renders this an inappropriate mechanism for

\footnotetext{
12 The Scottish device of trust is similar but different to the English device with the same name. See further G. L. Gretton, 'Trusts Without Equity', International Comparative Law Quarterly, 49 (2000), 599-620. The Scots law approach to trust property is that the trustees own that property and the beneficiaries of the trust have a strong right (but not an ownership right) to hold those trustees to account.

131944 SC 36. See Reid, The Law of Property in Scotland, paragraph 17.

${ }^{14}$ Gretton and Steven, Property, Trusts and Succession, paragraph 9.2. The other example normally given is of unincorporated associations, i.e. clubs. It might also be noted that partnerships in Scots law have a distinct legal personality (in terms of the Partnership Act 1890) and can own property outright without routing that directly through a co-ownership regime, although relationships within that partnership would then be governed by the partnership deed and the prevailing law relating to partnerships.

${ }^{15}$ D. Kleyn and S. Wortley, 'Co-ownership’ in R. Zimmermann, D. Visser and K. Reid (eds), Mixed Legal Systems in Comparative Perspective: Property and Obligations in Scotland and South Aftica (Oxford, Oxford University Press, 2004), 703-734.

${ }^{16}$ By way of an action of division and sale (sometimes called an action of division or sale, or known by the Latin actio communi dividundo), as confirmed by Upper Crathes Fishings Ltd v Bailey's Executors, 1991 SC 30. See also Morrison v. Kirk, 19112 SLT 335. English law observers may find some help from an analogy between common property and tenants in common.

${ }^{17}$ English law observers may find help here from an analogy between joint property and joint tenancy.

18 Theoretically, there is no upper limit to the number of co-owners: Menzies v Macdonald, (1854)16 D 827 affd (1856) 2 Macq 463, HL, discussed (and critiqued) in Reid, The Law of Property in Scotland, paragraph 28.

${ }^{19}$ With agreement amongst the co-owners, any otherwise lawful use would be possible; without such agreement, only ordinary use would be acceptable and no co-owner would be entitled to gain any excessive benefit: Carmichael v Simpson, 1932 SLT (Sh Ct) 16. Consider also Bailey’s Executors v Upper Crathes Fishing Ltd, 1987 SLT 405, where one co-owner successfully obtained an interdict (injunction) to stop another co-owner's excessive use of fisheries.
} 
long-term community ownership. ${ }^{20}$ Alternatively, they might form a specific trust, perhaps for a charitable purpose or another public goal relating to the target asset, and in those circumstances the trustees would find themselves in the regime governed by joint property. Both those situations would require a willing seller and a mutually agreeable price, which is no small assumption to make. As has been hinted above, Scottish land reform legislation steers communities into neither situation. Rather, it asks members of a community to form themselves into a legal vehicle - traditionally a company limited by guarantee ${ }^{21}$ - that does not have anything to do with co-ownership. Certain stipulations are made in relation to that vehicle's constitutional documents to make it community-oriented and representative, which will have implications for membership, office-holding and running of the entity, but otherwise matters of governance are left to the standard position for such entities.

\section{Commonty, Common Grazings and Common Good}

Tantalising as the above heading is, hinting as it does at three Scots institutions that revolve around common rights, the regimes for commonty, common grazings and common good are probably more of academic than practical interest. That is not to say they are completely irrelevant to modern Scotland (common grazings being particularly relevant to the system of landholding known as crofting), but it is to say they are idiosyncratic and it is not possible to give them more than a passing comment here.

Commonty is worth mentioning in the light of the foregoing discussion of co-ownership as a 'peculiar' right in common lands. ${ }^{22}$ Gordon and Wortley describe this as a right attached to a holding of separate property, giving holders of such property an additional right to the land comprising the commonty. They also note that in many instances the use of a commonty was such that it was 'difficult to determine whether the right held was the proprietary right of commonty, or merely a servitude of pasture or cutting peat. ${ }^{23}$ Whilst the latter situation would clearly be important to those able to exercise such rights, and (as discussed above) title conditions - of which servitudes (together with real burdens) are a subset - can play a role in

\footnotetext{
${ }^{20}$ The denouement in the Bailey's Executors v Upper Crathes Fishing Ltd saga was the already referenced case of Upper Crathes Fishings Ltd v Bailey's Executors. The co-owner who had been interdicted (enjoined) from that excessive use then raised an action to sell the asset, which the other co-owner could not object to. This highlights why this model can only work for as long as the parties are generally in agreement, and the absolute nature of the escape route means the standard situation of common property is not a realistic model for strategic community projects.

21 'Traditionally' might be too strong a word here, as the tradition only started in the 2003 Act (sections 34 and 71). The 2015 Act now allows Scottish charitable incorporated organisations (SCIOs) and community benefit societies to represent the community. The earlier Transfer of Crofting Estates (Scotland) Act 1997 (discussed below) was more flexible about the community bodies that the public sector could transfer its crofting assets to. ${ }^{22}$ W. M. Gordon and S. Wortley, Scottish Land Law, 3rd edn (Edinburgh, Thomson Reuters 2009), paragraph $15-179$.

${ }^{23}$ Gordon and Wortley, Scottish Land Law, paragraph 15-180. On servitudes (the Scottish equivalent term for 'easement'), see D. J. Cusine and R. R. M. Paisley, Servitudes and Rights of Way (Edinburgh, W. Green/Sweet \& Maxwell, 1998)
} 
the regulation of land in or by a community, it would not strictly be an example of communal ownership. ${ }^{24}$

Commonties were of a certain historic importance to Scotland, but since the Division of Commonties Act 1695 it has been possible for landowners abutting a commonty to have that commonty apportioned amongst them (after which the portions would be owned outright by the apportioned owner and no longer treated as part of a commonty). The activist Andy Wightman singled out this legislation in his land reform polemic, ${ }^{25}$ with chapter 7 of his book being dedicated to what he calls 'The fourth land grab - the commonties'. Whilst erosion of the commonties had taken place before that legislation, it was designed to achieve (and achieved) the acceleration of a move from land being held as commonties to pockets of outright ownership.

Although rarely encountered, ${ }^{26}$ there are occasional examples of commonties that escaped division, plus the seventeenth century legislation allowing for division did not apply to burgh (i.e. municipal) property. ${ }^{27}$ The exact extent of such land is not clear and there have been calls for further research into commonties. ${ }^{28}$ As it happens, the Scottish Government has tasked the Scottish Law Commission to look at commonties (and specifically the 1695 Act). ${ }^{29}$

\footnotetext{
${ }^{24}$ There could be some functional equivalence between mutual servitude holders and those having an ownership right in a thing. Such servitude holders would not have carte-blanche to do what they want. Co-dominant benefited proprietors (that is to say, dominant proprietors making use of the same servient tenement) have to sensibly manage their shared rights, both to not act to the detriment of the servient proprietor (through increasing the burden) and to avoid disputes between themselves. See G. J. Bell, Principles of the Law of Scotland, fourth edition (Edinburgh, 1839; reprinted as Old Studies in Scots Law, vol. 1, Edinburgh, 2010), § 988, and Alvis v Harrison, 1991 S.L.T. 64, and consider Carstairs v Spence, 1924 S.C. 380 and the related discussion in Cusine and Paisley, Servitudes and Rights of Way, paragraphs 12.196-12.201. For co-dominant proprietors, see Agnew v Lord Advocate, (1871) 11 M. 309, Yeaman v Mathewson, (1896) 12 Sh. Ct. Rep. 354 and the related discussion in Cusine and Paisley at paragraph 12.20.

${ }^{25}$ A. Wightman, The Poor Had No Lawyers: Who Owns Scotland (and How They Got it) (4 ${ }^{\text {th }}$ edn, Birlinn 2015), chapter 7.

${ }^{26}$ Writing in 1996, Professor Reid noted that 'Commonty is, or, perhaps more accurately, was a form of shared ownership of land for the purposes of grazing cattle or cutting peats.' (Emphasis added.) He went on to say 'It became rare in the modern period and it is not known whether any examples still survive.' Reid, The Law of Property in Scotland, paragraph 37.

${ }^{27}$ See the discussion in A. L. Jarman. 'Customary Rights in Scots Law: Test Cases on Access to Land in the Nineteenth Century’, Journal of Legal History, 28 (2007), 207-232. In terms of municipal resources, common good land will be considered below.

${ }^{28}$ One recent call came from Professor Gretton, in a book review of Wightman's aforementioned polemic: G. L. Gretton, 'Review: Andy Wightman, The Poor Had No Lawyers: Who Owns Scotland (and How They Got it)', Edinburgh Law Review, 15 (2011), 329-331. Jarman also bemoans the lack of Scottish research into commonties as compared to what has taken place in England, noting that, 'Today the subject of common land in Scotland is largely the purview of the informed activist and local authority lawyers rather than the academic scholar.' 'Customary Rights in Scots Law', 211-212.

${ }^{29}$ On 31 August 2016, Andy Wightman MSP (the same person who wrote The Poor Had No Lawyers, and now a Member of the Scottish Parliament for the Scottish Green Party) lodged a parliamentary question (S5W02239) asking 'what progress it is making with the review of the Division of Commonties Act 1695, and what discussions it has had with the Scottish Law Commission regarding the matter.' The relevant Cabinet Secretary responded (on 20 September 2016) to note that 'the Scottish Law Commission has agreed to consider the Division of Commonties Act 1695 as part of its next tranche of statute law repeals work.' See http://www.parliament.scot/S5ChamberOffice/WA20160920.pdf .
} 
Be that as it may, commonties are not common enough and probably not understood enough to provide a useful modern Scottish example of a practical open access resource. ${ }^{30}$

What is relevant in the present day is crofting law and, within that regime, the regulation of common grazings. These common grazings form a shared resource that crofters can use along with other members of a crofting locale. Used in this context, 'crofters' has a very specific statutory meaning. In statutory terms, crofting began in the late $19^{\text {th }}$ century in the Scottish Highlands and Islands, ${ }^{31}$ with crofters and (landless) cottars being organised into townships with shared common grazings. The entitlement to use those common grazings flows as a pertinent (which is a perk, or appertunance, to use land based on a right in other land) from a (very) secure croft tenancy. ${ }^{32}$ Traditionally, grazings would indeed have been used for the grazing of livestock, but with agreement amongst relevant parties these can be put to a variety of different uses, including forestry. ${ }^{33}$ Whilst there are just over a thousand of these common grazings in Scotland, ${ }^{34}$ it would be fair to say that the model is somewhat sui generis, and it can be noted that recent land reform measures have not embraced a wider application of the common grazings model for community rights in land.

Another potential point of interest relates to common good land, that is to say land that falls to be administered by a local authority in a certain capacity. ${ }^{35}$ The issue of common land around burghs has been touched on above, in the context of commonties that could not be subject to division in terms of the 1695 Act, and it has been noted that this dodging of enclosure meant that urban commons 'were an important feature in the urban-rural economy which existed up to the late eighteenth century in the larger towns and even later in the small

\footnotetext{
${ }^{30}$ A brief mention should be made of lands held runrig, a largely historic form of landholding that used to operate on a rotational basis. Runrig can be distinguished from commonty in that separate rights to the rigs (also called ridges, i.e. cultivation areas) were allocated to holders, but there are some similarities: runrig lands were also legislated for in 1695, by the Runrig Lands Act, which allowed for similar division and apportionment to take place; and runrig lands are also of limited importance in the present day. See Gordon and Wortley, Scottish Land Law, paragraphs 15-181-15-182.

${ }^{31}$ Crofting is a form of landholding associated with the so-called 'Crofting Counties' in the north and west of Scotland, which gives the crofter (tenant) almost absolute security of tenure. The legal framework that established crofters as creatures of statute began with the Crofters Holdings (Scotland) Act 1886 and is now found in the Crofters (Scotland) Act 1993. For an overview of the history of crofting, see J. Hunter, The Making of the Crofting Community (Birlinn, Edinburgh 2000) (first published 1976).

32 Since 1976, it has been possible for crofters to compel a transfer of both a house and croft land, with the rules for doing so currently being found in the Crofters (Scotland) Act 1993, sections 12-19, but the regulation of owner-occupier crofters is not something that will be explored here. The only point that will be mentioned is that owner-occupier crofters, despite buying out their landlord and thus freeing themselves from obligations that follow on from being a tenant, continue to have duties in relation to their land and that land is still subject to regulation by the Crofting Commission (that statutory body that regulates crofting). In the event they are somehow remiss in their management of the croft, enforcement action can follow, including being asked to let the land to someone else: the Crofters (Scotland) Act 1993, section 26J.

33 The Crofters (Scotland) Act 1993, sections 50, 50A and 50B. The relevant parties that would need to be involved in any decision would include other crofters, the owner, and the relevant statutory body.

${ }^{34}$ The Crofting Commission website notes there are 1,060 common grazings, covering over 500,000 hectares of land (approximately 6\% of Scotland's land mass). See www.crofting.scotland.gov.uk/facts-and-figures.

${ }^{35}$ A. C. Ferguson Common Good Law (Avizandum 2006)
} 
royal burghs' ${ }^{36}$ Division-proof as they were, they did not prove immune to erosion over time, ${ }^{37}$ with Wightman categorising the erosion of such land as another 'land grab' ${ }^{38}$

In terms of what assets in modern Scotland fall to be administered by local authorities, as successors to the old burghs and in turn the owners of common good property that was transferred to them, ${ }^{39}$ the Final Report of the Land Reform Review Group - a publication and a body that will be discussed further below - considered this and noted that in 2012 the combined value of Common Good Funds was considered to be over $£ 300$ million. ${ }^{40}$ Of that, '[b]y far the largest component ... is heritable [immoveable] property and while this mainly consists of public buildings and public spaces, such as parks, it also includes in some cases farm land and other heritable property, such as salmon fishings. ${ }^{41}$ Much recent reform has been aimed at establishing and publicising what the extent of these holdings is. ${ }^{42}$ It is nevertheless clear that such assets are important to communities across Scotland. In turn, what the municipal embodiment of a community ${ }^{43}$ is able to do with such property is important, and a specific and somewhat esoteric reform in the newest land reform legislation is designed to make it easier to change the use common good land is put to. ${ }^{44}$

As with the brief looks at commonty and common grazings above, it is difficult to extrapolate lessons for community ownership as a whole from common good land, but it is clear that the use of such assets can be important to communities across Scotland. There are many other important reference points for community involvement in local land decisions, including community councils, ${ }^{45}$ the wider planning process, and indeed the accountability of public

\footnotetext{
36 Jarman, 'Customary Rights in Scots Law', 212 quoting I. H. Adams, 'The Legal Geography of Scotland’s Common Lands', 2 Revue de l’Institut de Sociologie (1973), 259-323.

${ }^{37}$ There was some notable resistance: consider A. C. Loux, 'The Great Rabbit Massacre - A "Comedy of the Commons”? Custom, Community and Rights of Public Access to the Links of St Andrews', Liverpool Law Review, 22 (2000), 123-155, and the related case of Dempster v Cleghorn (1813) 2 Dow 40 (HL).

${ }^{38}$ Wightman, The Poor Had No Lawyers, chapter 8. As to what caused this erosion, Wightman offers the view that there was corruption and bad governance, which (in property law terms) could result in gains for individual proprietors who benefited from the operation of rules of positive prescription (adverse possession) to validate acquisitions. (The modern equivalent rules of positive prescription are found in Part 1 of the Prescription and Limitation (Scotland) Act 1973.)

${ }^{39}$ By the Local Government (Scotland) Act 1973, sections 222(2) and (3).

40 The Land Reform Review Group, The Land of Scotland and the Common Good (The Scottish Government: Edinburgh, 2014), Section 14 - Common Good Lands, paragraph 2.

${ }^{41}$ The Land Reform Review Group, The Land of Scotland and the Common Good, Section 14 - Common Good Lands, paragraph 1.

42 The 2015 Act, Part 8. This is in line with the recommendation that 'the position over Common Good lands should be improved to ensure they are adequately safeguarded and appropriately managed. The Group recommends that a new statutory framework should be developed to modernise the arrangements governing Common Good property.' The Land Reform Review Group, The Land of Scotland and the Common Good, Section 14 - Common Good Lands, paragraph 21.

${ }^{43}$ It is acknowledged that treating local authorities as actually equivalent to an embodiment of a local community is a stretch, given the geographical size of some of Scotland's 32 local authorities.

44 The 2016 Act, section 77. This reform was largely driven by a case to do with the siting of a new school on a park in Edinburgh: Portobello Park Action Group Association v City of Edinburgh Council [2012] CSIH 69. See further M. M. Combe, 'Lessons in Scots law: the common good school', Edinburgh Law Review, 17 (2013), 63-68.

45 These are statutory bodies established by the Local Government (Scotland) Act 1973 that play a consultative role in the planning process. More recently, they and certain other properly constituted community bodies have been given a role where they can enter into devices reminiscent of title conditions called 'good neighbour
} 
bodies or the Crown that own or manage land in Scotland. Important as those and other features might be, this chapter will now consider the community rights found in Part 2, Part 3 and Part 3A of the 2003 Act and Part 5 of the 2016 Act, all of which seek to empower communities by giving a route to ownership of land. Before doing that, it will briefly explain why there has been a drive for such reform.

\section{Community Rights of Acquisition}

\section{Why is land reform happening in Scotland?}

To an extent, the appetite for Scottish land reform, and in turn the widening of community involvement with land, is amply demonstrated by the simple fact of the recent legislative steps. That still raises a few questions. Why is there such an appetite? Why now? What are the alternatives? ${ }^{46}$

Taking the 'Why now?' question first, as it is the most easily dealt with, a crucial factor was the establishment of the Scottish Parliament. The Scotland Act 1998 introduced a unicameral legislative forum with the time and the inclination to embrace land law reform when it brought devolution to Scotland. The new Parliament was spurred on by the formation of the Land Reform Policy Group ${ }^{47}$ ('LRPG') chaired by Lord Sewel, at the instigation of the Labour government that was swept into power by the 1997 General Election. ${ }^{48}$ The inaugural elections for a Scottish Parliament returned a Labour/Liberal Democrat coalition, who took the LRPG's recommendations forward in a variety of legislative measures in the first term of the new devolved administration. The most important of these for present purposes was the 2003 Act, which brought two community rights of acquisition. ${ }^{49}$ In this first wave of activity, the Scottish Parliament also legislated on matters relating to property law more generally and specifically in relation to the heavily regulated agricultural holdings sector. ${ }^{50}$

That goes some way to explain and demonstrates why those initial years of devolution been so fertile for land reform, but why is there a continuing appetite for more?

\footnotetext{
agreements' in relation to land, in terms of the Town and Country Planning (Scotland) Act, section 75D. See further M. Combe, 'Good neighbour agreements - bad law?', Journal of the Law Society of Scotland, 52(8) (2007), 50-53.

${ }^{46}$ Questions such as this have been considered by the author elsewhere. See Combe, 'Parts 2 and 3 of the Land Reform (Scotland) Act 2003: A Definitive Answer to the Scottish Land Question?', M. M. Combe, 'The environmental implications of redistributive land reform’, Environmental Law Review , 18 (2016), 104-125, and M. M. Combe, 'The Land Reform (Scotland) Act 2016: another answer to the Scottish land question', Juridical Review, 2016, 291-313.

47 Three publications were produced by the Land Reform Policy Group and published by the Scottish Office: Identifying the Problems (1998); Identifying the Solutions (1998); and Recommendations for Action (1999).

${ }^{48}$ Of course, land reform literature predates this era, including J. McEwen, Who Owns Scotland (EUSPB: Edinburgh, 1977). It would also be simplistic to attribute all relatively modern reforms to the Labour victory in 1997, as it was a Conservative Government who implemented the Transfer of Crofting Estates (Scotland) Act 1997 discussed below.

${ }^{49}$ A number of related statutes were also passed, such as the already mentioned Abolition of Feudal Tenure etc. (Scotland) Act 2000 and the Title Conditions (Scotland) Act 2003.

${ }^{50}$ As regulated by the Agricultural Holdings (Scotland) Act 1991 and the Agricultural Holdings (Scotland) Act 2003 (asp 11).
} 
The so-called Scottish land question, which essentially turns on how land in Scotland is owned and used, has lingered for many years. The occasionally turbulent history in (parts of) Scotland may have played a part in that, ${ }^{51}$ but the manner in which the land of contemporary Scotland is owned and organised in the present day as measured against contemporary commitments to sustainability and sound land management for economic, social and environmental goals continues to cause comment.

Whilst history might be relevant to some, it has not been a major driver for contemporary Scottish land reform. There has been no overt attempt to right a historical wrong against an identifiable community. ${ }^{52}$ Scottish land reform also contrasts with other jurisdictions that have sought to provide subsistence agriculture for those who are hungry or shelter for those who are destitute, although notions about food security, sanitation and housing have been creeping into the Scottish debate, as a positive rights-based driver for land reform. ${ }^{53}$

The drivers towards land reform that have been used include arguments about local enterprise or complaints that the pattern of landownership in Scotland is such that there is dominance by major players in the land market. ${ }^{54}$ To make a proper analysis of whether this is a problem for Scotland can be difficult or laborious, owing to the occasionally patchy information about who owns what available at present. That patchiness is twofold: clear data is not always

\footnotetext{
${ }^{51}$ Many resources are available. For the Highlands and Islands, consider Hunter, The Making of the Crofting Community, and for the Lowlands consider T. M. Devine, 'Social Responses to Agrarian "Improvement”: The Highland and Lowland Clearances in Scotland' in R. A. Houston and I. D. Whyte (eds) Scottish Society 15001800 (Cambridge University Press, Cambridge, 1989) 148-168.

52 This contrasts with, for example, one aspect of South Africa’s land reform programme: D. L. Carey Miller with A. Pope, Land Tenure in South Africa (Cape Town, Juta, 2000), particularly chapter 7; J. M. Pienaar, Land Reform (Cape Town, Juta, 2014), p. 209 and chapter 9.

53 To the extent that s. 98 of the 2003 Act has been amended (by the 2015 Act) to make explicit reference to the International Covenant on Economic, Social and Cultural Rights, which in turn raises the issues of food, sanitation and housing. It can be noted that a rights-based argument for reform can quickly be met by a rightsbased argument against reform, as a landowner has a human right to peaceful enjoyment of her possessions except where that is disturbed in the public interest (non-arbitrarily and generally with compensation). Two cases provide useful examples of what is and is not acceptable in human rights terms and (in turn) the devolution settlement established by the Scotland Act 1998. What is not acceptable is made clear in a series of cases about the Agricultural Holdings (Scotland) Act 2003, culminating in the UK Supreme Court case of Salvesen $v$ Riddell [2013] UKSC 22. The various steps of that saga are analysed in M. M. Combe, 'Human rights, limited competence and limited partnerships: Salvesen v Riddell', Scots Law Times (News), 2012, 193200, 'Peaceful enjoyment of farmland at the Supreme Court', Scots Law Times (News), 2013, 201-203 and 'Remedial Measures in Agricultural Holdings', Scots Law Times (News), 2014, 70-71. What is acceptable is a properly considered piece of legislation that provides for the reallocation of property rights within a statutory scheme that allows a landowner to make representations throughout: Pairc Crofters Limited and Pairc Renewables Limited v. The Scottish Ministers [2012] CSIH 96. That saga is analysed in M. M. Combe, 'Ruaig an Fhèidh', (2011) 56(5) Journal of the Law Society of Scotland 54-55 and 'Ruaig an Fhèidh: 3', (2013) 58(2) Journal of the Law Society of Scotland 31-33.

54 There are hints at a critical view of monopolies in the Final Report of the Land Reform Review Group, where it is noted that present voluntary good land management practices 'should not disguise the fact that they do so at their own discretion and that the present arrangements provide limited sanctions against those who do not. This situation arises because of the degree of 'monopoly' control large land owners effectively have over land and other community interests, in ways that can determine the future of whole localities: The Land of Scotland and the Common Good, Section 24 - Pattern of Rural Land Ownership, paragraph 25.
} 
available on public registers for land; ${ }^{55}$ and there can be a lack of clarity about who controls the landholding entity that is registered as owner. ${ }^{56}$ Meanwhile, a recent paper submitted to the Scottish Affairs Committee at Westminster suggests a figure in the region of 432 landowners own $50 \%$ of the privately owned land in Scotland. ${ }^{57}$ That is a striking figure, ${ }^{58}$ which also raises issues, beyond the scope of this essay, of social justice and fairness across society. Another possibility is that reform is about the governance of land, which is particularly seen to be an issue when landowners are termed as 'absentee' (a point which can be compounded when a non-active, non-resident owner is also non-transparent). To simplify, the argument would be that land is better governed when those who live or work on the land have a stake in its governance. This might bring related benefits in terms of population retention or revitalisation. Whether a community is the best candidate to take on the governance of land is a tricky question. Organisations like Community Land Scotland strongly advocate the case for it, ${ }^{59}$ but there are issues as to whether any incoming owner, community or otherwise, will have necessary skills when it comes to land management, whilst some have cautioned against models of community ownership that trap communities into their own circumstances. ${ }^{60}$

All of this gives a flavour of what has fed into the land reform debate in Scotland. The next thing to consider is where the community features as a result of that debate.

\footnotetext{
${ }^{55}$ Scotland has operated a system of deeds registration for the transfer of land since the Registration Act 1617, before moving to a map-based system of registration of title that has been phased in since the Land Registration (Scotland) Act 1979. The transition has been slow, but is perhaps nearing resolution, with both the Scottish Government and Registers of Scotland committing to a rapid completion of the coverage of the Land Register to the whole of Scotland, in line with the recent Land Registration etc. (Scotland) Act 2012. See further: http://news.scotland.gov.uk/News/Target-set-to-register-all-of-Scotland-s-land-cc8.aspx.

${ }^{56}$ In proceedings at the Rural Affairs, Climate Change and Environment Committee of the Scottish Parliament in the run-up to the 2016 Act, an estimate that some 750,000 acres of Scotland was owned via non-transparent entities was discussed and not doubted (Official Report of the Rural Affairs, Climate Change and Environment Committee, 7 September 2015 Report, Col 71 (Scottish Parliamentary Corporate Body: Edinburgh) at http://www.scottish.parliament.uk/parliamentarybusiness/report.aspx?r=10075\&mode=pdf. The figure appears in the magazine Private Eye Issue 1395 (26 June 2015). The transparency point has also been made by Wightman, The Poor Had No Lawyers, chapter 29. These concerns have led to legislation aimed at improving access to information about who controls land, in Part 3 of the 2016 Act.

57 J. Hunter, P. Peacock, A. Wightman and M. Foxley (with a foreword by Ian Davidson MP), 432:50 -

Towards a comprehensive land reform agenda for Scotland: A briefing paper for the House of Commons (Scottish Affairs Committee, 2013) available at http://www.parliament.uk/business/committees/committees-az/commons-select/scottish-affairs-committee/news/land-reform-inquiry/. By 'privately owned', state owned land is excluded, so the land owned by Forestry Commission Scotland (via the Scottish Ministers) does not feature in that analysis.

${ }^{58}$ See A. McKee, C. Warren, J. Glass, and P. Wagstaff, 'The Scottish Private Estate’ in J. Glass, M. F. Price, C. Warren and A. Scott, Lairds, Land and Sustainability (Edinburgh, Edinburgh University Press, 2013) 62-85, p. 65, where it is observed (drawing on the work of Kevin Cahill and others) that 'Scotland has the most concentrated pattern of private ownership in Europe, and possibly the world.' A similar statement is made by Monbiot (also drawing on the work of Cahill) about Britain as a whole when he states that 'we have one of the highest concentrations of landownership in the world’: G. Monbiot, Feral (London, Penguin, 2014), p. 107. See further K. Cahill, Who Owns Britain (Edinburgh, Canongate, 2002).

${ }^{59}$ See www.communitylandscotland.org.uk.

${ }^{60}$ Consider Antinori, who notes that 'devolving responsibility may "enslave” local indigenous groups to the natural environment.’ C. Antinori, ‘Governance and Resource Management in Mexico’s Community Forestry Sector' in J. Holder and C. Harrison, Law and Geography (Oxford, Oxford University Press, 2003), 307-321, p. 310.
} 


\section{Community-oriented Scottish land reform}

As already noted, the 2003 Act brought in two rights of community acquisition which were innovative for Scotland. The measures gave rural communities ${ }^{61}$ a right of first refusal over assets (Part 2) and crofting communities a right to force a sale of certain crofting assets (Part 3). Flagship as this legislation was, it was not actually the first statute to put local communities to the fore. The first real statutory intervention came in the form of the Transfer of Crofting Estates (Scotland) Act 1997. This legislation provides for transfer of crofting lands owned by the state, to a community body. That community body would then become a crofting landlord. The highly regulated crofting scheme that governs such land would mean no particular change of land use would be possible by the incoming owner in the event of a transfer, meaning the actual 'on the ground' land reform effect of this measure was always destined to be limited. ${ }^{62}$ As it happens, its effect was limited anyway, as only one crofting community has availed itself of the legislative scheme.

That being said, a real impact of the 1997 Act was to propel community into the thinking of those framing legislative intervention, but that was not the only factor. Many important examples of community ownership in Scotland came about as a result of community action that did not wait for legislation. ${ }^{63}$ The community acquisitions of the islands of Eigg and Gigha (amongst others) pre-dated such developments, and those trailblazing communities have generally fared well: both witnessed population increases since transfer to their respective community. ${ }^{64}$ That is not to say communities are insulated from all challenges of land management. The Isle of Gigha Heritage Trust has faced some documented issues, particularly in relation to the debt owed by the community landowning entity (and secured on its land) post acquisition. ${ }^{65}$

Mention of the Isle of Gigha Heritage Trust provides an opportunity for an important aside, as explained in the foregoing discussion about co-ownership: community landowners who have acquired land without reference to any statutory scheme have tended to channel that community through one landowning entity, with a structure and membership that can be tailored to suit them (and any funders) without any community property ownership legal constraints.

\footnotetext{
${ }^{61}$ Rural communities were (initially) classed as those with a population of 10,000 people or less: see The Community Right to Buy (Definition of Excluded Land) (Scotland) Order 2004 (SSI 2004/296).

62 There are processes to remove land from the control of crofting law, known as resumption and decrofting, but both are somewhat convoluted and no analysis will be made of them here.

63 See J. Bryden and C. Geisler, 'Community-based land reform: Lessons from Scotland', Land Use Policy, 24 (2007), 24-34.

64 J. Hunter, From the Low Tide of the Sea to the Highest Mountain Tops: Community Ownership in the Highlands and Islands of Scotland (Kershader, The Islands Books Trust, 2012). As regards the community acquisitions that have taken place under the 2003 Act, see C. Mulholland, G. McAteer, C. Martin, L. Murray, R. Mc Morran, E. Brodie, S. Skerratt and A. Moxey, 'Impact Evaluation of the Community Right to Buy' (Edinburgh, Scottish Government Social Research, 2015) at http://www.gov.scot/Publications/2015/10/8581. 65 The Sunday Herald, 'A tale of two islands as Gigha dream turns sour' 23 November 2014, at http://www.heraldscotland.com/news/13190772.A tale_of two_islands_as_Gigha_dream_turns_sour/. I wrote a blog post in response to this: 'Gigha dream turns sour? Community ownership in Scotland' 23 November 2014 at https://basedrones.wordpress.com/2014/11/23/gigha-dream-turns-sour-community-ownership-in-scotland/.
} 
Taken together with the 1997 Act, these extra-statutory developments in Scotland and the means by which they were achieved, showcased community models to the Land Reform Policy Group. The LRPG went on to embrace community models in its work, without any particular study of comparative models of land reform. ${ }^{66}$

Land reform did not particularly feature in the second and third terms of the Scottish Parliament, ${ }^{67}$ but after the Scottish National Party won a majority in the 2011 election it appointed a group to look at land reform in 2012 to fulfil a manifesto commitment. This Land Reform Review Group ('LRRG') produced its Final Report in 2014, containing 62 recommendations as to what the Scottish Government should do, ${ }^{68}$ but not before the then First Minister Alex Salmond announced (in 2013) a commitment to bringing 1 million acres of Scotland (approximately one-twentieth of its land area) under community ownership. ${ }^{69}$

With community having such a central role somewhat pre-judged at that highest level of government, with the groundwork of existing community landowners, and with those existing legislative schemes to look at, it is not surprising that the Final Report looked closely at community options. It did this in several ways. In addition to exhorting the Scottish Government to take steps to look after any coelacanth common land or commonties that come to light, ${ }^{70}$ it suggested establishing a working group to find out what is owned by communities ${ }^{71}$ and developing a 'strategic framework to promote the continued growth of local community land ownership'. ${ }^{72}$ It went on to suggest community rights should be made

\footnotetext{
${ }^{66}$ International analysis was somewhat lacking in the work of the Land Reform Policy Group. More recently, Scottish civil servants have engaged in welcome comparative work: see the Scottish Parliament Information Centre Briefing 15/38, International Perspectives on Land Reform (Edinburgh , SPICe, 2015), at http://www.scottish.parliament.uk/parliamentarybusiness/91179.aspx. Interestingly, the Executive Summary of that Briefing indicates that Scotland may be swimming against the tide in its fondness for community ownership, which is 'in contrast to the apparent European trend towards increasing land consolidation. The Community Right to Buy and Crofting Community Right to Buy...are correspondingly unique pieces of existing legislation, despite the growing Community Land Trust movement in North America and Europe, and draft legislation in Kenya that seeks to restore and register community land rights.'

${ }^{67}$ Which is not to say no land related statutes were passed: consider the Crofting Reform etc. Act 2007, the Private Rented (Housing) Scotland Act 2011 and the Wildlife and Natural Environment (Scotland) Act 2011. 68 The Land Reform Review Group, The Land of Scotland and the Common Good. See further M. M. Combe, 'Land Reform Revisited: The Land of Scotland and the Common Good', Edinburgh Law Review, 18 (2014), 410-413. The author was appointed an Adviser to the Group in 2013.

69 'I believe it is possible, I believe it is necessary for us to set a target of one million acres of Scotland in community land ownership by 2020’: Alex Salmond, speaking at the Community Land Scotland Annual Conference, 2013, quoted at http://www.gov.scot/Topics/Environment/land-reform/MillionAcres. Further details of the Scottish Government's steps in this area can also be found at that link.

70 'The Group recommends that these distinctive forms of land tenure should be identified and safeguarded as part of modernising Scotland's system of land ownership.' The Land Reform Review Group, The Land of Scotland and the Common Good, Section 7 - Ownerless Land, paragraph 11. As noted above, steps are being taken by the Scottish Government to ascertain how relevant commonties continue to be in modern Scotland. ${ }^{71}$ The role of this group 'would be to improve existing information on the numbers and types of community land owners and the land that they own, and to develop a strategy for achieving this target.' The Land Reform Review Group, The Land of Scotland and the Common Good, Section 16 - Land and Community Development, paragraph 15.

72 The Land Reform Review Group, The Land of Scotland and the Common Good, Section 16 - Land and Community Development, paragraph 18.
} 
less bureaucratic and expanded to urban areas, ${ }^{73}$ and that 'statutory land rights of local communities should include a right to register an interest in land, the existing right of preemption over land and a right to buy land, as well as rights to request the purchase of public land and to request Scottish Ministers to implement a Compulsory Purchase Order. ${ }^{74}$ There was also a specific recommendation for a 'Community Land Agency, within Government, with a range of powers, particularly in facilitating negotiation between land owners and communities, to promote, support and deliver a significant increase in local community land ownership in Scotland. 75

Following this there was a further Holyrood consultation about what the promised Bill should include, ${ }^{76}$ after which the Stage 1 draft of the Bill was released. ${ }^{77}$ Not all of the recommendations of the Final Report of the LRRG were included. Some were destined for the separate but related statute on community empowerment. The 2015 Act amended the 2003 Act, widening the scope of its pre-emptive community right to buy to the whole of Scotland (rather than simply rural Scotland, in line with the recommendation of the LRRG) ${ }^{78}$ and finessing the existing scheme to make it more user-friendly. It also introduced provision for communities to make 'asset transfer requests' from their local authority, which must be considered by that local authority in light of a statutory scheme and cannot simply be rejected out of hand. ${ }^{79}$ Most importantly for present purposes, it introduces a new right of community acquisition where land has been 'wholly or mainly abandoned or neglected' or somehow managed in a way that was detrimental to a community's 'environmental wellbeing'. ${ }^{80}$

\footnotetext{
${ }^{73}$ On less bureaucracy, there was a call for greater flexibility as to what comprised an appropriate community body, which has been catered for by moving beyond simply companies limited by guarantee. On the expansion to urban areas, see the 2015 Act, s. 36, which amends the 2003 Act, s. 33. These reforms came into force on 15 April 2016, under The Community Empowerment (Scotland) Act 2015 (Commencement No. 3 and Savings) Order 2015 (SSI 2015, No. 399).

${ }^{74}$ Section 17 - Local Community Land Rights, paragraph 27. A similar but slightly different recommendation also made in Section 17 was that communities 'should have the right to request that a local authority exercises a Compulsory Sale Order’ (at paragraph 33).

${ }^{75}$ Section 19 - Community Support Services, paragraph 20. Reference can be made here to the Scottish Government funded Community Ownership Support Service delivered by the Development Trusts Association Scotland, at www.dtascommunityownership.org.uk.

${ }^{76}$ Consultation on the Future of Land Reform in Scotland (2014), at www.gov.scot/Topics/Environment/landreform/consultation.

${ }^{77}$ Intriguingly, the Scottish Affairs Committee got involved in the debate at a UK level. Although no Westminster legislation followed (or is likely to follow) from that intervention, the Committee gathered evidence and published two reports which add to the contemporary debate: see Scottish Affairs Committee, Eighth Report - Land Reform in Scotland: Interim Report (2014), at http://www.publications.parliament.uk/pa/cm201314/cmselect/cmscotaf/877/87702.htm and Scottish Affairs Committee, Eighth Report - Land Reform in Scotland: Final Report (2015) at http://www.publications.parliament.uk/pa/cm201415/cmselect/cmscotaf/274/27402.htm. Its contribution to community ownership was to query 'whether parts of the tax system are pushing up land prices and undermining a commitment to increasing community land ownership’: Final Report, Conclusion and Recommendation 7 and paragraph 26.

78 The 2015 Act, section 36, which amends the 2003 Act, section 33.

${ }^{79}$ The regime as a whole is found in the 2015 Act, Part 5. It commenced on 23 January 2017, per The Community Empowerment (Scotland) Act 2015 (Commencement No. 4 and Transitory Provision) Order 2016 (SSI 2016/363)

80 The 2015 Act, section 74, introducing a new Part 3A to the 2003 Act.
} 
As regards the most recent Land Reform (Scotland) Bill, at Stage 1 it included a 'right to buy land to further sustainable development' for communities, whilst provision was made to give guidance to landowners about consultation with local communities when making decisions about land. A Call for Evidence about the actual terms of that Bill was made by the relevant scrutinising Scottish Parliament Committee, then three stages of parliamentary and related committee scrutiny followed. ${ }^{81}$ Although there was some sculpting of the provisions about communities, the general model stayed the same throughout the legislative process.

\section{How does this suite of legislation work?}

\section{First wave community rights of acquisition}

The 2003 Act works by allowing a community body (i.e. members of a locality associated together in a suitable juristic persona) to acquire land in certain circumstances. For communities in crofting areas of the Scottish Highlands and Islands looking to acquire ownership of land under crofting tenure, common grazings and certain eligible additional land, a sale can be forced on an unwilling seller. For communities seeking to acquire land under Part 2 of the 2003 Act, there are two crucial differences. The right is of first refusal, meaning the owner cannot be forced to transfer and the community right will only trigger when the owner decides to transfer the land. Relatedly, a community must register an interest in the land it seeks to acquire in a public register, to put the landowner on notice of its plans. ${ }^{82}$ Whilst the owner cannot be forced to sell under Part 2, this is still an important power for the community to have, and one that is stronger than the right to bid that applies in England and Wales as a result of Part 5 of the Localism Act 2011. ${ }^{83}$ That legislation only provides a right to bid for targeted asset of community value, whereas the Scottish legislation provides that a transferring landowner must sell to the community at an agreed or set price.

The schemes in Parts 2 and 3 both involve a number of preparatory steps, the first of which is incorporation of a suitable entity that acts as its embodiment. This body that community members are channelled into will then own the land outright, on a single title. Where the body is a company limited by guarantee, its articles of association must be tailored so as to have not fewer than 10 members, provision that at least three quarters of the members of the company are also members of the local community (with a related stipulation that those members have control of the company), and provision that any surplus funds or assets of the company are to be applied for the benefit of the community. If an alternative form of Scottish charitable incorporated organisation or community benefit society is opted for, then similar

\footnotetext{
${ }^{81}$ See Rural Affairs, Climate Change and Environment Committee, Stage 1 Report on the Land Reform (Scotland) Bill (2015) at

http://www.parliament.scot/S4_RuralAffairsClimateChangeandEnvironmentCommittee/Reports/RACCES0420 15R10Rev.pdf.

${ }^{82}$ The 2003 Act, section 36. The Register of Community Interest in Land is maintained by the Keeper of the Registers of Scotland and is available at http://rcil.ros.gov.uk/RCIL/default.asp?category=rcil\&service=home. ${ }^{83}$ Whilst the Scottish regime in Part 2 cannot force a sale to a community, as a landowner can choose to no longer sell at any point in the transaction, it does mean a properly constituted community body with a registered interest cannot be forced to contend with a new landowner for that asset it has targeted. This is because any transfer that did not first consider the community could be open to challenge. The moratorium under the Localism Act 2011 gives communities a (relatively weaker) right to bid.
} 
rules apply, mutatis mutandis. In all cases, the body must have been recognised by Scottish Ministers as having a commitment to sustainable development. ${ }^{84}$ The community is then left to operate in a suitably sculpted regime under the Companies Act 2006, the Co-operative and Community Benefit Societies Act 2014 or the Charities and Trustee Investment (Scotland) Act 2005 (asp 10) (as applicable).

Whilst more flexibility has undeniably been introduced by allowing these two forms to be adopted by communities as alternatives to a company limited by guarantee, it can be noted that there are more flexible schemes in operation for certain community bodies recognised in other Scottish statutes. The most notable comparator is the Transfer of Crofting Estates (Scotland) Act 1997, section 2, which simply needs a body (corporate or unincorporated) to be approved by the Secretary of State, after consultation with the Crofting Commission) that it is 'representative of the crofting interests in the property to be disposed of' and 'has the promotion of the interests of persons residing on such property as its primary objective'. There is similar flexibility the 2015 Act, section 19, which allows a body (again, corporate or unincorporated) with certain simple constitutional requirements to make participation requests of certain public bodies (allow it to get involved with the delivery of service) and asset transfer requests of a local authority in the aforementioned fashion. ${ }^{85}$

Once a suitable body has been formed, there must also be evidence of local support. In terms of the Part 2 right of pre-emption, evidence is needed at the beginning of the acquisition process, ${ }^{86}$ followed by a ballot to ensure majority support before exercise of the right itself. ${ }^{87}$ Even then acquisition will only be possible with the approval of the Scottish Ministers. That approval will only be forthcoming if the acquisition is in the public interest and compatible with furthering the achievement of sustainable development. ${ }^{88}$ The (repeated) role of sustainable development in this statute has been described as a 'primary duty' on the decision-makers which 'has priority over any other duties or objectives', ${ }^{89}$ so its application and interpretation is of crucial importance. ${ }^{90}$ Assuming a community steers itself through

\footnotetext{
${ }^{84}$ Sections 34(4) and 71(4) of the 2003 Act provide that Ministers must have given the body 'written confirmation that they are satisfied that the main purpose of the body is consistent with furthering the achievement of sustainable development.'

${ }^{85}$ Another less than favourable comparison for 2003 Act and 2016 Act community bodies is provided in relation to the bodies that can enter into good neighbour agreements, discussed in Combe, 'Good neighbour agreements - bad law?'

${ }^{86}$ In most circumstances, support will be demonstrated when at least $10 \%$ of the population approve, in terms of section 38. There are also special and more stringent rules in section 39 for 'late applications'. These are applications that are rushed by a community after land has been exposed for sale by the owner, and in those circumstances there is a higher threshold in relation to community support.

87 Ballots are required for the ultimate exercise of a right to buy under section 52 of the 2003 Act. The approval process for crofting community bodies is in section 75 .

${ }^{88}$ Section 51(3)(c) and (d) (for the Part 2 community right to buy) and section 74(1)(j) and (n) (for the Part 3 crofting community right to buy). There is also an extra requirement for sustainable development in Part 2 where a community seeks to register an interest to acquire land that is near (rather than within) that community: section 38(1)(b)(ii).

${ }^{89}$ A. Ross, Sustainable Development in the UK: From Rhetoric to Reality? (Abingdon, Earthscan, 2012), p. 191.

${ }^{90}$ In relation to sustainable development, see Combe, 'Parts 2 and 3 of the Land Reform (Scotland) Act 2003: A Definitive Answer to the Scottish Land Question?’, 219-222. There has been litigation relating to what is expected of communities, with Holmehill Limited $v$ The Scottish Ministers 2006 S.L.T. (Sh Ct) 79 making clear
} 
these provisions, the land is then transferred at an agreed or independently valued price. ${ }^{91}$ There are provisions that allow the owner to input into or appeal about the overall process throughout.

\section{Second wave community rights of acquisition}

The 2003 Act will soon have a new Part 3A, introduced by the 2015 Act. ${ }^{92}$ Section 74 of the 2015 Act enshrines a right which goes beyond pre-emption, meaning this new entitlement has something in common with the crofting community right to buy in that it will not require a willing seller. Properly constituted community bodies, which track the requirements set out above, are to be given the right to acquire 'eligible land' if (in the opinion of Scottish ministers): '(a) it is wholly or mainly abandoned or neglected, or (b) the use or management of the land is such that it results in or causes harm, directly or indirectly, to the environmental wellbeing of a relevant community'. Again, there is a role for Scottish Ministers, who must consent to the acquisition and they will only do so when satisfied that the land is in fact eligible (i.e. abandoned, neglected or environmentally detrimental) and that the exercise of the right is both in the public interest and compatible with furthering the achievement of sustainable development. ${ }^{93}$ These provisions are not yet in force.

\section{Third wave community rights of acquisition}

The 2016 Act contains a wide range of important measures, with much of it being dedicated to the matter of agricultural holdings reform and other provisions for diverse issues like deer management, fiscal reform of the tax treatment of land used for shooting, and a new body called the Scottish Land Commission to monitor matters relating to land. In terms of community land specifically, Part 5 provides for a community right to acquire land to further sustainable development, again adopting a community-centric model not unlike Parts 2, 3 and 3A of the 2003 Act, albeit with an onerous process that communities might find it difficult to get through. The process is onerous because this right of acquisition does not require a willing seller: when the statutory tests are met, and subject to payment of an agreed or independently valued price, transfer is compelled.

Where the 2016 Act differs from the other community rights of acquisition is in asking that more hurdles than public interest and sustainable development are cleared. The transfer of land must also be likely to result in 'significant benefit' to the relevant community, and must be 'the only practicable, or the most practicable, way of achieving that significant benefit'. ${ }^{94}$ There is then a further test that 'not granting consent to the transfer of land is likely to result

a community should tread carefully if a main driver for the attempt to acquire land is to thwart development, as discussed in M. M. Combe, 'No Place like Holme: Community expectations and the right to buy', Edinburgh Law Review, 12 (2006), 109-116.

91 The 2003 Act, sections 59-60A and 88.

92 See further M. M. Combe, 'Digesting the Community Empowerment Act', Journal of the Law Society of Scotland, 60(8) (2015), 40-41. The Scottish Government has suggested these will come into force in the summer of 2017 http://www.gov.scot/Topics/People/engage/CommunityEmpowermentBillFAQs.

93 The 2003 Act, section 97H, to be introduced by the 2015 Act, section 74.

94 The 2016 Act, section 56(2)(c). 
in harm to that community' ${ }^{95}$ Those additional conditions bring the ideas of 'significant benefit' and 'harm' to the fore, both of which are to be determined by an analysis of a community's economic development, regeneration, public health, and social and environmental wellbeing. ${ }^{96}$ Another innovative feature of Part 5 as compared to the other rights of acquisition is that a community may nominate a third party acquirer, albeit the transfer to such a nominee would still need to meet all the tests already mentioned, mutatis mutandis. Whilst this might not open up a form of community ownership, it could open up funding and partnership arrangements that have not been possible under existing statutory schemes.

Also of interest from a community perspective is the way Parts 4 and 5 of the Act are tied together. Ministers can take into account the extent to which landowners have had regard to guidance issued under section 44 (about engaging a community with decisions affecting land) in determining whether an application to buy land under Part 5 meets the 'sustainable development conditions' for a community buyout. ${ }^{97}$ This means the guidance could be important in certain contexts when a community tries to force a sale.

\section{What effect have the measures had so far?}

There have been a number of community transfers under the scheme of Part 2 of the 2003 Act, albeit the impact has not been profound in terms of numbers of activated community interests in the Register of Community Interests in Land. ${ }^{98}$ In terms of qualitative rather than quantitative impact, recent Scottish Government commissioned research seems to indicate positive trends for communities and other benefits across a range of aspects. ${ }^{99}$ The scheme is not a one way street for communities though: there have been occasions when communities have faced challenge in court, and indeed certain communities who thought they were progressing along the land reform process (having obtained Scottish Ministerial consent for that) have been challenged through litigation. ${ }^{100}$

\footnotetext{
95 The 2016 Act, section 56(2)(d).

96 The 2016 Act, section 56(12). None of these terms are defined, but environmental wellbeing features in the right of acquisition in part 3A of the 2003 Act, section 97C(2)(b), to be introduced by the 2015 Act, section 74.

97 The 2016 Act, section 56(4)).

9819 of the 208 registered interests have been activated: http://rcil.ros.gov.uk/RCIL/default.asp?category=rcil\&service=home. Perhaps this lack of profound impact should not be surprising, as it was noted prior to enactment of the 2003 Act (by Ross Finnie MSP, the then Minister for Environment and Rural Development) that this right was not designed for 'significant redistribution of land': Justice 2 Committee, Stage 1 Report, paragraph 75 (SP Paper 541 at http://archive.scottish.parliament.uk/business/committees/historic/justice2/reports-02/j2r02-02-vol01-02.htm\#2). ${ }^{99}$ See C. Mulholland, G. McAteer, C Martin, L Murray, R Mc Morran, E Brodie, S Skerratt and A Moxey, 'Impact Evaluation of the Community Right to Buy' (Scottish Government Social Research: Edinburgh, 2015) at http://www.gov.scot/Publications/2015/10/8581. This looked at the impact of the legislation on local communities in the period from 2004 to 2014.

${ }^{100}$ Consider the cases of Holmehill Limited $v$ The Scottish Ministers 2006 SLT (Sh Ct) 79 and Hazle v Lord Advocate (Kirkcaldy Sheriff Court (ref B270/07), 16 March 2009), discussed and critiqued in Combe, 'No Place Like Holme’ and M. M. Combe, 'Access to Land and to Landownership’, Edinburgh Law Review, 14 (2010), 106-113 respectively. See also West Register (Property Investments) Ltd. v Lord Advocate 11 March 2015, Selkirk Sheriff Court (unreported), discussed in K. G. C. Reid and G. L. Gretton, Conveyancing 2015 (Edinburgh, Avizandum, 2016), pp. 37-39.
} 
The impact of the crofting community right to buy, or at least the potential spectre of it, has been more noticeable. This too has been the subject of litigation, but the one 'hostile' 101 buyout eventually resulted in a transfer to the relevant community, after the landowner's challenge to the scheme of Part 3 based on the European Convention of Human Rights was unsuccessful. ${ }^{102}$ It has also contributed to various transfers of land (particularly in the Western Isles) in the limited area where it operates without the need to resort to litigation. ${ }^{103}$ All of this chimes with earlier commentary that Part 3 of the 2003 Act marks a 'fairly radical step away from the traditional protection afforded to Scotland's landowners'. ${ }^{104}$ As for the provisions in Part 3A of the 2003 Act and Part 5 of the 2016 Act, time will tell.

\section{Conclusion}

There is no doubt that recent measures are making Scotland something of a contemporary case study for land reform. Its community-centric approach also makes it a case study for those interested in community rights. ${ }^{105}$ Within wider questions of whether Scotland should engage in a land reform process at all, there are sub-questions about who gets to benefit. Whilst there are some individual rights of acquisition available to certain tenants in Scotland, ${ }^{106}$ these are somewhat sidelined in comparison to the community-oriented approach.

It might be that Scotland stumbled into its particular model community-oriented land reform, but this chapter should provide some detail about how it can work in theory and in reality. As to whether Scotland can be a model for other jurisdictions, an American professor's observations about the 2003 Act might be of interest at this juncture. This chapter has tried to demonstrate that the 2003 Act (and indeed other legislation) was important for communities in Scotland, but the 2003 Act's provisions were also important for rights of responsible

\footnotetext{
${ }^{101}$ Press and Journal, 'Pairc Estate in hands of community after Scotland's first hostile land buyout' 6 December 2015 https:/www.pressandjournal.co.uk/fp/news/islands/771128/estate-in-hands-of-community-after-scotlandsfirst-hostile-land-buyout/ The Pairc dispute also highlighted the need for remedial legislation, in the form of a new s 69A of the 2003 Act which was introduced by the Crofting Reform etc. Act 2007, following on from the case of Scottish Ministers v Pairc Trust Ltd 2007 SLCR 166.

102 Pairc Crofters Limited and Pairc Renewables Limited v The Scottish Ministers, [2012] CSIH 96. See further Combe, 'Ruaig an Fhèidh' and Combe, 'Ruaig an Fhèidh: 3’.

103 See Hunter, From the Low Tide.

${ }^{104}$ D. L. Carey Miller and M. M. Combe, 'The Boundaries of Property Rights in Scots Law', Electronic Journal of Comparative Law, 10.3 (December 2006), http://www.ejcl.org/103/art103-4.pdf, 6. Radical as that change is to a property lawyer, MacKenzie has argued that the real radical effect of Part 3 is the 'troubling of the norms of property law through which class interest is brokered', and it was the 'threat to the commodification of land' that was behind certain opposition to land reform; A. F. D. MacKenzie, Places of Possibility: Property, Nature and Community Land Ownership (Somerset, NJ, USA, John Wiley \& Sons, 2012), p. 48.

${ }^{105}$ Bryden and Geisler, 'Community-based land reform: Lessons from Scotland'.

${ }^{106}$ Crofters have an individual right to buy in terms sections 13-19 of the Crofters (Scotland) Act 1993. Tenants of agricultural holdings have to a right of first refusal over that tenanted land (introduced by Part 2 of the Agricultural Holdings (Scotland) Act 2003), and will soon have an additional right to acquire from a landlord who has repeatedly done something wrong, namely when a landlord is in material breach of an order of the Scottish Land Court or an arbitral award: see the new Part 2A to the Agricultural Holdings (Scotland) Act 2003, introduced by section 100 of the 2016 Act.
} 
outdoor access in Scotland. ${ }^{107}$ In an article that looked at the access rights introduced by Part 1 of the Land Reform (Scotland) Act 2003 in some detail, Lovett noted that the statute demonstrated 'it is practically possible for a modern, democratic nation committed to the rule of law, the protection of private property, and open markets to create, if it wants, a property regime that to a considerable extent replaces the ex ante presumption in favor of the right to exclude that has come to be taken for granted in the United States with an equally robust, but rebuttable, ex ante presumption in favor of access.' ${ }^{108}$

Similarly, it is submitted the rights of community acquisition introduced to Scots law have not caused unwarranted or unjustified detriment to Scotland's rule of law, the protection of private property, and open markets. Much like recent land registration innovation has been heralded as 'evolution, not revolution', ${ }^{109}$ the same could be applied to the communityoriented reforms Scotland has entered into to date. Observers from Scotland and beyond will be watching closely to see whether the same is true in relation to the new waves of land reform legislation that will be introduced in the coming months.

\footnotetext{
${ }^{107}$ See further R. R. M. Paisley, Access Rights and Rights of Way (Edinburgh, The Scottish Rights of Way and Access Society (Scotways), 2006) and M. M. Combe, 'Get Off That Land: Non-Owner Regulation of Access to Land', Juridical Review, 2014, 287-317.

108 J. A. Lovett, 'Progressive Property in Action: The Land Reform (Scotland) Act 2003', Nebraska Law Review, 89 (2011), 739-818, 816-817.

${ }^{109}$ G. L. Gretton, 'The shape of things to come', Journal of the Law Society of Scotland, 55(3) (2010), 22-25, 22 (the innovation being the Land Registration etc. (Scotland) Act 2012 (asp 5)).
} 